\title{
Man Alone/Mulgan/Marxism
}

\section{DOUGAL McNEILL}

One must assume the inheritance of Marxism, assume its most 'living' part... This inheritance must be reaffirmed by transforming it as radically as will be necessary. Such a reaffirmation would be both faithful to something that resonates in Marx's appeal - let us say once again in the spirit of his injunction - and in conformity with the concept of inheritance in general.

Jacques Derrida, Spectres of Marx ${ }^{1}$

As this essay concerns itself with missed chances, an appropriate image with which to open proceedings: what could Adorno and Mulgan have talked about on their train journey from Paris to Dieppe? Mulgan was returning from a failed League of Nations meeting; Europe was travelling towards Serge's 'midnight of the century'. ${ }^{2}$ A weary dispiritedness characterizes both thinkers' correspondence from the time. O'Sullivan's biography tells us the two had lunched in Oxford in the mid-1930s and, a little later, Mulgan wrote of the 'little philosopher that [he] had known slightly at Oxford, a German emigre.' Adorno remembered Mulgan as 'generally speaking an interesting man ... working here as a reader for OUP, a Marxist., ${ }^{3}$ It is hard to imagine two more different characters. Mulgan the good keen man, an all-but-aRhodes-scholar, almost bluff, down-to-earth, suspicious of intellectual women, and Adorno, with his 'big nut-brown eyes like a child's, lively as an elf, curious about everything and willing to talk ... drawn as if by a magnet to young girls with aristocratic names'. ${ }^{4}$ Their dissimilarities represent two different strands in socialist culture, a certain empiricism and what is to become 'Western Marxism'. What they talked about was of sufficient interest for them both to record the encounter - and 'generally speaking an interesting man' is strong stuff from the notoriously circumspect and scathing Adorno - but, of course, we are never to know that conversation's contents. Considering Marxism's tenuous and barren status within New Zealand literary-critical culture in the years since, and thus the thinness and provisionality of what passes for my tradition here, I cannot help but invest in the spectre of this conversation, with its promise of a creative encounter we can imagine and yet never reconstruct.

Marxism, Mulgan, and Man Alone have had a curious relationship in the seventy or so years since the book's publication. For the most part, within other countries' canons, historical materialism's great battles have involved the struggle to force recognition of the political and ideological grounding of literature - the political unconscious and literary theory as political criticism, to evoke two central texts from the 1980s - and interventions insisting on political material unrecognized or distorted in conventional treatments of prominent texts. Historical materialism has thus, whether acting to 'force a given interpretive practice to stand and yield up its name, to blurt out its master code and thereby reveal its metaphysical and ideological underpinnings' or, claiming a Blake or a Brontë for the tradition, seen a good deal of its work as having to do with uncovering and revealing the hitherto concealed and repressed. ${ }^{5}$

This method seems, at first, wholly inappropriate for the field around Man Alone. For a generation now the consensus within the mainstream of New Zealand literary scholarship has identified Mulgan's as a deeply political and, indeed, socialist novel. C.K. Stead, in an insightful essay thirty years ago, described Man Alone as 'a novel which is basically Marxist in structure' and recently Alex Calder has summarized the novel as 'a textbook Marxist 
analysis of the economic basis of New Zealand society'. ${ }^{6}$ In the decades between these two claims Rachel Barrowman wrote that 'Man Alone carries a Marxist theme in its depiction of the impact of economic forces upon society'. ${ }^{7}$ Mulgan's 'political outlook' is, for Stuart Murray, a 'vital element of any reading of Man Alone' and, Murray contends, it is one that is 'more or less evacuated by nationalist criticism." ${ }^{8}$ The historical context and detail offered by each of these works is important; as I shall quarrel with each of them in what follows, it is important to register here the value of what I have learnt from them all. What, amongst all this association of Mulgan and Marxism, though, is the relationship between these terms? My contention is that 'Marxism' is, in the scholarly literature to hand, an under-thought term, one referring to at once too much and too little of Mulgan's legacy and his 'remarkable half-life' since 1945 to be of much critical use. ${ }^{9}$ The association of Mulgan and Marxism has been made, perhaps, too readily, and too glibly. There is a messier, and, potentially, more productive, encounter between the two yet to be staged.

\section{What is Mulgan for Marxism?}

It comes as some surprise, after the associations made in literary history and criticism, to turn for signs of Man Alone in the archive of New Zealand Marxism and to find there are almost none. After an insightful review by James Betram in Tomorrow on May Day 1940 there were few chances for the novel and the socialist currents in New Zealand to engage with each other: Tomorrow was suppressed by the Labour Government, as were the Communist Party's various papers, and the war interrupted Man Alone's New Zealand reception. ${ }^{10}$ The situation after the novel was reissued in 1949 is more surprising, though. I have been able to find no reference to Man Alone in any of the journals produced as a result of splits from the Communist Party of New Zealand over Hungary or Stalinism: neither Comment, Socialist Forum, Here and Now, nor New Zealand Monthly Review discuss or mention Man Alone. ${ }^{11}$ Each of these journals carried reports on both contemporary and 'classic' literature, and so Mulgan's absence signifies more than a general philistinism. Man Alone's absence from the Monthly Review is all the more striking when one considers its longevity - the journal appeared for over thirty years - and its association with important cultural figures such as Bill Pearson.

Man Alone is missing, too, from the great revival of Marxist thinking in the New Left. Socialist Action, a fortnightly paper edited by Keith Locke and others, never once mentioned Mulgan in the twenty years it appeared. He is absent from the more theoretical Red Papers on New Zealand put out by the Marxist Publishing Group around David Bedggood at Auckland University in the middle of the 1970s, and goes unmentioned in the New Zealand New Left's smaller publications, too: no essays or appreciations in Bruce Jesson's Red, Spartacist Spasmodical, Owen Gager's Dispute or in Salient when it was under Marxist control.

(Some readers may, at this point, produce $\mathrm{H}$. Winston Rhodes as a counter-example, but Rhodes' peculiar blend of Stalinism and literary appreciation prevented him from offering more than banalities on the 'adequate human symbol' and 'the problem of the solitary man': whatever his personal political affiliations, Rhodes' critical interventions are the exception proving my rule. Who is the major New Zealand Marxist critic? H. Winston Rhodes, hélas.) ${ }^{12}$

I list these non-appearances in order to emphasize the peculiar place Man Alone occupies: in print more-or-less continuously since its publication; a canonical work central to discussions of New Zealand literary history; associated with the Left and claimed, by critics as different as Stead and Calder, to have a 'basically Marxist' structure, Man Alone seems the ideal candidate for interrogation by historical materialism. And yet this is the text about which Marxism itself has had close to nothing to say. The silence seems significant. 


\section{What is Marxism for Mulgan?}

'we need to interpret interpretation more than to interpret things.'

For all that Mulgan scholarship is content to label Man Alone as Marxist, little is made of this particular description. Barrowman sees the novels 'Marxist theme' in 'its depiction of the impact of economic forces upon society and the individual. ${ }^{13}$ But this is a 'Marxism' so wide it could be used to describe everything from Middlemarch to Midsomer Murders, and thus loses any sense of analytical purchase or precision.

More thorough is Alex Calder's summary, and endorsement, of Stead's account of what Calder glosses as Mulgan's 'rather schematic analysis':

Johnson, the drifter, serves as a traditional picaresque hero moving the action and the analysis from place to place, and also as an ideological dupe. ... There is a flaw in his system: the economic 'base' of a society is its fundamental reality, and the coming Depression exposes the limits of Johnson's freedom. A 'man alone' can't change things; a spontaneous revolution like the Queen Street riots will be contained, but purposeful collective action offers the way forward. ${ }^{14}$

This has the advantage of specificity, and the scare quotes placing the term 'base' at suitable distance from Calder's own voice remind us of the notorious base-superstructure model which is, allegedly, the heart of Marx's reductive enterprise. Certainly, Man Alone's narrator offers direct commentary on the riot in keeping with Calder's analysis: 'the forces of disorder could not win; they could express themselves, but while they existed in disorder, they could gain nothing. ${ }^{, 15}$ The Queen Street riot, on this reasoning, is an expression of a certain despair - the act of 'ideological dupes' perhaps - but not, on its own, an historical act. The 'Marxism' of Man Alone is to be found in its hard-nosed recognition of this fact. Its 'essentially Marxist analysis of the period of New Zealand history' (the terms are Stead's) and 'quite deliberately Marxist' design and 'initial Marxist intention' in these sections is to show how '[a]s men lose their collective identity [in the rioting] and become individuals (men alone) purity of action and of motive is lost. ${ }^{16}$ Calder is right to label this 'rather schematic analysis.' What is less clear is how it relates to Marxism.

It might be useful here, considering Stead and Calder's association of 'Marxist intention' with the passages in Man Alone that depict the rioters 'drunk with excitement' as 'ideological dupes,' to cite Jim Edwards, the Communist Party's leading figure in the Unemployed Workers' Movement gaoled for his role in the Queen Street riots, and to contrast his assessment of the events with Stead and Calder's reconstructed 'Marxism':

Yes, it was a terrible night, but we busted the credit of this country both in the United States and in Europe and I verily believe that the result was the overthrow of the Government at that time and the installation of the Labour Party in power. And for that, with all due modesty, I take full credit. ${ }^{17}$

This gives some sense of the Communists' own assessment of the role of the riots, and indicates an attitude and tenor quite different to that literary criticism has assigned to communist theory. I read into the record Lenin's more general, but significant, theoretical aside:

To imagine that social revolution is conceivable without revolts by small nations in the colonies and in Europe, without revolutionary outbursts by a section of the petty bourgeoisie with all its prejudices, without a movement of the politically non-conscious 
proletarian and semi-proletarian masses against oppression by the landowners, the church, and the monarchy, against national oppression, etc. -- to imagine all this is to repudiate social revolution. So one army lines up in one place and says, 'We are for socialism', and another, somewhere else and says, 'We are for imperialism', and that will be a social revolution! Only those who hold such a ridiculously pedantic view could vilify the Irish rebellion by calling it a 'putsch'. Whoever expects a 'pure' social revolution will never live to see it. Such a person pays lip-service to revolution without understanding what revolution is. ${ }^{18}$

Mulgan, whatever his own views, would very likely have been familiar with this passage - it is a famous polemic in Marxist history, and a staple for citation since Lukàcs drew on it in his Lenin (1924), one someone associated with the Left Book Club would be bound to have read or heard. Its political outlook and tone indicate a tradition very different from the one ascribed to 'Marxism' by Stead and Calder.

Mulgan's relationship with the Marxist tradition, and, in turn, its place in Man Alone, is a good deal more complicated than the existing critical literature acknowledges. Mulgan describes himself in Report on Experience as a 'keen pre-war reader of Tom Wintringham and Trotsky', drawing attention to the critical and independent currents he engaged with, and emphasizing his distance from the 'official' socialism of the communist party in New Zealand or Britain. ${ }^{19}$ References to Wintringham and Trotsky - the one expelled, the other murdered by Stalinist counter-revolution - would have had an explosive charge in the context of their first publication, and underline both Mulgan's wide, and heterodox, reading and ideological affiliations (the association with Adorno, another dissident Marxist, is significant here too), and point to something of the paucity and poverty of New Zealand criticism's sense of Marxism. Recall Derrida's quotation from Montaigne at the beginning of 'Structure, Sign and Play': 'we need to interpret interpretation more than to interpret things'. 20 'Marxism', in the Mulgan criticism I've examined so far, serves not as a proper name for the body of thought associated with historical materialism and the socialist project but is, rather, a signifier standing to block inquiry in that direction. Associating Man Alone with a caricatured Marxism of their own creation (Calder's 'rather schematic analysis') allows liberal criticism to bypass the novel's ideological and political context on the way to its own concerns.

Symptomatic here is the bulk of criticism's association of Marxism with analysis of story and an accompanying neglect of questions of narrative discourse, of writing itself. Calder describes it as a 'textbook Marxist analysis'; for Barrowman they are 'Marxist themes'; Stead detects a Marxist 'intention'. None of these critics considers the socialist political questions or inheritance of the novel at the level of writing, as a matter of the ideologies of form. The critics' own concerns receive close reading and a quite different treatment (national identity and father-son relations for Stead, genre and borrowing for Calder), and yet Marxism figures as crude parable or allegory 'behind' the text.

The presence of Marxism in the writing around Man Alone matches, in this way, the absence of Man Alone from New Zealand Marxism: both indicate that, seventy years after the novel's first publication, we are still without an encounter between Marxism and Man Alone.

\section{Our Only Hope - Contradictions!}

'Accordingly, what I would postulate is more dialectics. ${ }^{, 21}$

I would like, at this point, to evoke that train journey again. Adorno was, around the time he was travelling with Mulgan, engaged in an intensive correspondence with Walter Benjamin, explaining the reasons why the Institute for Social Research would not publish Benjamin's 
submissions. (Part of this correspondence was published in the late 1970s by New Left Books as Aesthetics and Politics). Central to these debates was the question of the relationship between literary form and historical knowledge. What forms of writing were adequate to represent monopoly capitalism? 'The impossibility of realism', for Adorno, 'is not to be concluded on inner-aesthetic grounds but equally on the basis of the historical constellation of art and reality.' ${ }^{22}$ For Marxist circles, outside the deadening philistine spaces of the Stalinized Communist Parties and their various cultural front groups, the 1930s were a period of intensive debate on the ideologies of form. Brecht's first theoretical writings date from this period, as does Trotsky and Breton's 'Manifesto for an Independent Revolutionary Art', experiments in 'flat' writing, loudspeaker theatre, the experimental novels of Grassic Gibbon, and John Heartfield's photomontages. (A telling detail reveals a carelessness with this material: Alex Calder refers to 'Trotskyites', a term from Stalinist sources and unused now for many decades). ${ }^{23}$

This is the context for James Bertram's description of Man Alone as 'an attempt to apply to this country the technique of bare realism', and his comparison of Mulgan with Lewis Grassic Gibbon and Sean O'Casey. ${ }^{24}$ Both Grassic Gibbon and O'Casey were outside 'offical' Communist Party of Great Britain circles, and their writing represented attempts to innovate within the realist tradition, producing what John Roberts has called 'modernist realism' or 'postclassical realist avant-garde art'. ${ }^{25}$ 'Bare' or 'modernist' realism are, too, in implicit contrast, and polemic opposition, to the official 'socialist realism' of the Stalinists. A reading of Man Alone out of this tradition - a tradition Adorno and Mulgan would have been well placed to debate as they journeyed across France, when they may well have pondered how 'new problems appear and demand new methods' - would be a reading of the politics of style. ${ }^{26}$ Marxist criticism of this period examined texts not for their 'themes' or 'analysis' (the vocabulary of idealist criticism here exposing the shallowness of earlier criticism's sense of Man Alone's Marxism); that is the small change Adorno sneered at as 'the blatantly obvious in the trivial wisdom those doctrines supposedly communicate. ${ }^{27}$ We might want to register, instead, the pressure of ideology as it works itself out in the texture and form of the novel. Marxism might, in other words, read Mulgan's novel as a novel, and not as a just-so story illustrating 'schematic analysis'.

Having situated Mulgan's 'technique of bare realism' Bertram is quick to insist 'I don't mean that Man Alone is a great novel: it's a good first novel, with a good many obvious faults. ${ }^{28}$ Might these 'obvious faults' have offered a space Marxist criticism could have investigated, starting, in the method of Brecht's 'bad new things,' by following Adorno's instruction: 'more dialectics'? ${ }^{29}$ A particular unevenness strikes the reader. From the beginning, Man Alone offers passages of 'bare realism' that seem to indicate allegiances to Brecht's 'alienation effects', Benjamin's 'critical montages' or other 'modernist realist' techniques of defamiliarization. Looking at New Zealand's farm country 'was like seeing a new country open out like the raw edges of a wound', and rural capitalism is represented, early in the novel, as part of the wider social formation: '[m]ilking at Blakeway's was as much like working in a factory as anything else'. ${ }^{30}$

Mulgan's representation of the Queen Street Riots, the illustration each previous account of his 'Marxism' has focussed on, is important for this reading, but for quite different reasons. Parts of Chapter Six read as 'bare realism' or Benjamin's 'literary montages' ('I needn't say anything, merely show'). ${ }^{31}$ The very flatness of the style gestures towards the ambitions of dissident Marxist literary culture for cinematic literature and novels able to represent the social totality: 
In the centre of the crowd where the street lamps were shining, he could see a man addressing the unemployed marchers, held up on his shoulders, his cap pulled up and waving in the air, the light shining on his sweating face. Johnson could see him, his mouth moving and his face working but could not hear what he said. The crowd moved round and round him like a broken tide-rip. ${ }^{32}$

This is not the dominant style through this passage, though, and there the shift from this 'bare realism' back to an older, more comfortably omniscient stance jars. Who editorializes here? Are these thoughts those of the implied author, Johnson's, or those of the unnamed narrator from the heterodiegetic level of the novel's 'Introduction'?

They were outside in the streets and had won their fight and were free from restraint ... To them it was the releasing of accumulated desire, a payment for the long weeks and months of monotony and weariness and poverty and anxiety that could be satisfied like this in a few moments of freedom and destruction. ${ }^{33}$

We recognize here the voice of the outraged liberal shrinking in horror from the mob, and what follows is, stylistically and ideologically, as much Alan as John Mulgan: 'those who fought by the windows for what they could take were not real fighters, but the scavengers, not the front line, but the trailings and conscripts'. ${ }^{34}$ This tone of hostility to the poor, and to social conflict and mass action, is as familiar today from the London riots of 2011 as it would have been to the Chartists of the 1840s. It is useful here to contrast Man Alone to Marx himself, who claimed that workers' 'riots' and 'acts of frenzy' are 'provoked' by 'utter destitution and by the cool insolence of their masters'. 35

The stylistic unevenness of these passages, and the uncertainty of narrative mode they reveal (to whom do those banalities belong?) indicate the ideological fissures marking the text. Man Alone contains within itself contradictory political and aesthetic impulses. It strains towards representations of mass action and worlds where there 'were so many people that no one cared for individuals' but is repelled by the actuality of mass activity, 'the crowd' and Lenin's 'movement of the politically ... non-conscious masses'. ${ }^{36}$ It is a novel which worries away at the 'great solitude' and the 'heaviness of the bush' that can oppress and disfigure in a social formation where 'most of the time a man spends too much time alone', and yet it is most imaginatively alive in its narration of a man alone so that, as Alex Calder suggests, 'a "man alone" myth soon crystallized around the book, despite its pointed statement of a contrary theme'. ${ }^{37}$ Far from offering any easily-extracted set of Marxist themes and didactic talking points, then, Man Alone exposes itself as an ideologically divided and incoherent text, one marked by the presence of a certain Marxist style it is anxious, at other times, to exorcise and negate.

The Marxist criticism forming in Europe at the time of Man Alone's composition would have taken these textual problems, and not the themes, intentions and 'analysis' of Stead, Calder and Barrowman, as its problem. Two enemies' mottos both offer productive methods here: Brecht's 'contradictions are our hope!' and Adorno's aside that 'scars of damage and disruption are the modern's seal of authenticity' both point to ways a Marxist criticism might have encountered Man Alone as a piece of writing. ${ }^{38}$

That encounter, though, never happened, and we have no way of knowing what Mulgan and Adorno talked about during their encounters together. Fascism, Stalinism, war and distance combined to prevent the translation or circulation of the dissident Marxist texts of the 1930s for decades after their first appearance and, in a setting characterized by a hegemonic New Criticism and embattled local anti-Stalinist currents, Marxist literary criticism in New Zealand was stillborn. Man Alone and Marxism have been associated for 
decades, but seem never to have met. For what culture could have contained them? Tuwhare's career within the Communist Party, and Mason's decades' long silence, indicate the barren ground of a local Stalinism. The splits and disintegration of New Zealand Stalinism led, not to the relative openness and liberality of Eurocommunism, but to ever increasing isolation and dogma, first from Beijing, followed, farcically, by Tirana. If those political considerations retarded the growth of a Marxist criticism of Man Alone, its reception in the aesthetic field was no easier. By the time the New Left made available an audience for the arguments of an Adorno or a Brecht, the questions and demands of the local literary culture pushed leftists in directions quite apart from Mulgan's project.

One sign of this non-encounter is the continuing habit, in political criticism, of moralizing readings of the text's story at the expense of its narrative discourse. Christina Stachurski is not alone in reading Man Alone more or less as a thesis or project, a 'late colonial text' working to transform space into place: 'the novel's implied re-colonization is predicated on the absence of Maori from ... New Zealand's representative core. ${ }^{39}$ The strength of this claim is not my concern here so much as the reductive arrogance of its approach: how would Stachurski account for the moment the narrator informs us that 'Mabel's grandfather had shot Maoris for his bit of land'? ${ }^{40}$ Reading Man Alone for its 'message' - colonialist homophobia in this instance - allows us to feel all the more content in our own complacent enlightenment and the wonderfulness of the present:

Nothing is settled: the questions continue to be played out in the creative texts, in the stories we tell ourselves. At least now, though, many more voices can be heard and the questions are more complicated. ${ }^{41}$

If this is the end-point of moralizing postcolonial criticism - I am reminded of Marx's line about the Young Hegelians, 'those sheep, that take themselves and are taken for wolves' - then imagining Man Alone's missed encounter feels all the more urgent, with the force behind it of a present-day demand. ${ }^{42}$

\section{The inheritance}

I began this essay with the figure of Adorno, and want to end with him too. In the beginning of the first of his Three Studies of Hegel, Adorno identifies, and rejects, the complacent historical smugness motivating Croce's question 'what is alive and what is dead in Hegel's philosophy'? Instead, Adorno insists, the correct attitude to a great thinker must instead be the reverse: we must ask how we would look to them, how our predicaments might be framed by the work before us. ${ }^{43}$

Something of Adorno's method is applicable as we read Mulgan. I have attempted to reconstruct something of the focus of a Marxist criticism of Mulgan from his own era in order to show that the dominant account of this side of his work's politics not only distorts the tradition it claims to affiliate with Man Alone, but also to suggest that there are other losses, imaginative and methodological, this distortion carries alongside itself. That criticism can, in one sense, never happen; Brecht's was an historical materialism, and recognized the connection of the object of a committed criticism with the political possibilities open to its practitioners.

There is no use in nostalgia. We cannot, from this distance, recreate that Marxist encounter. Thinking about its motivations, though, and pondering the priorities it might have set itself from within its own tradition, might suggest richer paths for our own reading and research.

It feels appropriate, thinking about a novel that ends with a strange image of survival through un-death to make clear in conclusion my own motivations here. Man Alone can, 
restored to this context, become part of an inheritance. And an inheritance, of course, 'is never a given, it is always a task. It remains before us just as unquestionably as we are heirs of Marxism, even before wanting or refusing to be and, like all inheritors, we are in mourning. ${ }^{44}$ 'There are some men, this fellow said, you can't kill', so the task, instead, may be picking up politically unfinished business. ${ }^{45}$

\footnotetext{
${ }^{1}$ Jacques Derrida, Spectres of Marx: The State of Debt, the Work of Mourning, and the New International, translated by Peggy Kamuf, London, 1994, p.54. Emphasis in original.

${ }^{2}$ Victor Serge, Midnight in the Century, London; Paris, 1939.

${ }^{3}$ Both quoted in Vincent O'Sullivan, Long Journey to the Border: A life of John Mulgan, Auckland, 2003, p.172. The Oxford lunch is mentioned on p.130.

${ }^{4}$ The description is Rossana Rossanda's. Rossana Rossanda, The Comrade from Milan, translated by Romy Clark Giuliani, London, 2010, p.180.

${ }^{5}$ Fredric Jameson, The Political Unconscious: Narrative as a Socially Symbolic Act, London, 1981, p.43.

${ }^{6}$ C.K. Stead, In the Glass Case: Essays on New Zealand Literature, Auckland, 1981, p.72; Alex Calder, The Settler's Plot: How Stories Take Place in New Zealand, Auckland, 2011, p.219.

${ }^{7}$ Rachel Barrowman, A Popular Vision: the Arts and the Left in New Zealand 1930 - 1950, Wellington, 1991, p.5.

${ }^{8}$ Stuart Murray, Never a Soul at Home: New Zealand Literary Nationalism and the 1930s, Wellington, 1998, p.200.

${ }^{9}$ The term is Patrick Evans', from his The Long Forgetting: Post-colonial Literary Culture in New Zealand, Christchurch, 2007, p.148.

${ }^{10}$ There is still no substantial published history of the Communist Party of New Zealand, to compare to, say, Stuart MacIntyre's work in Australia. For now see Kerry Taylor's essential 'Workers Vanguard of People's Voice? The Communist Party of New Zealand from its Origins to 1946', PhD Thesis: Victoria University of Wellington, 1994.

${ }^{11}$ Neither Comment nor Here and Now were always explicitly socialist journals, so their position is rather more complicated. Paul Day published an article on Man Alone in Comment, although this was not a discussion claiming Mulgan for Marxism. Sid Scott published two articles on 'Marxism and Literature' in Here and Now October and November 1954; neither mentions New Zealand writing.

${ }^{12}$ H. Winston Rhodes, New Zealand Novels: a Thematic Approach, Wellington, 1969, pp.61, 29.

${ }^{13}$ Barrowman, p.5.

${ }^{14}$ Calder, p.219.

${ }^{15}$ John Mulgan, Man Alone, Hamilton, 1960, p.64.

${ }^{16}$ Stead, pp.80, 81, 82.

${ }^{17}$ Mulgan, p.57. Jim Edwards, Break Down These Bars, as told to David Ballantyne, Auckland, 1987, p.50.

${ }^{18}$ V.I. Lenin, 'The Discussion on Self-Determination Summed Up', in Collected Works, Volume 22, Moscow, 1960, p.358. Emphasis in original.

${ }^{19}$ John Mulgan, Report on Experience, ed., Peter Whiteford, Wellington, 2009, p.84. Whiteford glosses this with a note on Wintringham emphasizing his advocacy of guerrilla warfare training for the Home Guard. Equally significant, for Mulgan's politics, is Wintringham's role in the Common Wealth Party and his break with the Communist Party of Great Britain. Mulgan's 'Editorial Note' to Songs of Freedom is equally puzzling: he describes the collection as 'an effort to represent the liberalism of poetry in its oldest and widest sense', more or less in keeping with the Popular Front line of the Communist Party of Great Britain at the time, but then thanks Hugh MacDiarmid, who had been recently expelled from the Party and would thus, for the Stalinist fellow travellers of Victor Gollancz, been a 'non person'. See Songs of Freedom, London, 1938, pp.11, 16.

${ }^{20}$ Jacques Derrida, Writing and Difference, translated by Alan Bass, London, 1978, p. 278.

${ }^{21}$ Adorno, letter to Walter Benjamin, 18 March 1936, Aesthetics and Politics, p.124.

${ }^{22}$ Theodor Adorno, Aesthetic Theory, translated by Robert Hullot-Kentor, London, 1997, p.322.

${ }^{23}$ Calder, p.223. Chapter Seven of Murray's Never a Soul at Home is an excellent account of Mulgan's international political context. As his work is literary history more than criticism, though, this material is never integrated into accounts of Mulgan's texts themselves.

${ }^{24}$ James Bertram, 'Between Two Wars', Tomorrow, 1 May 1940, p.404; Flight of the Phoenix: Critical Notes on New Zealand Writers, Wellington, 1985, p.38.

${ }^{25}$ See John Roberts, 'Realism, Modernism, and Photography', in Matthew Beaumont, ed., Adventures in Realism, Oxford, 2007, p.175.

${ }^{26}$ The term is Brecht's, from his 'Popularity and Realism', in Theodor Adorno, Walter Benjamin et al, Aesthetics and Politics, London, 1977, p.82.
} 
${ }^{27}$ Adorno, p.104.

${ }^{28}$ Bertram. Man Alone is not italicized in the original Tomorrow article.

${ }^{29}$ Adorno, letter to Walter Benjamin, 18 March 1936, Aesthetics and Politics, p.124.

${ }^{30}$ Mulgan, pp.18,19.

${ }^{31}$ Walter Benjamin, The Arcades Project, London, 2002, p.460.

${ }^{32}$ Mulgan, p.54.

${ }^{33}$ Ibid., p.56.

${ }^{34}$ Ibid., p.57.

${ }^{35}$ Karl Marx, New York Daily Tribune, 4 November 1853. Cited in Karl Marx and Frederick Engels, Collected Works, Volume 12, London, 1979, p.400.

${ }^{36}$ Mulgan, pp.58, 200.

${ }^{37}$ Ibid., pp.141, 142, 200. Calder, p.218.

${ }^{38}$ Bertolt Brecht, Brecht on Theatre: the Development of an Aesthetic, edited and translated by John Willett, London, 1964, p.47; Adorno, p.23.

${ }^{39}$ Christina Stachurski, Reading Pakeha? Fiction and Identity in Aotearoa/New Zealand, New York, 2009, pp.34, 16.

${ }^{40}$ Mulgan, p.22.

${ }^{41}$ Stachurski, p. 176.

${ }^{42}$ Karl Marx and Fredrick Engels, The German Ideology, translated by W. Lough, London, 1965, p.23.

${ }^{43}$ See Theodor Adorno, Three Studies of Hegel, Cambridge, 1994, p.1.

${ }^{44}$ Derrida, p.40.

${ }^{45}$ Mulgan, p.207. 